\title{
Interpretation of Aeromagnetic Anomalies over Abeokuta, Southwest Nigeria, Using Spectral Depth Technique
}

\section{*BELLO, RASAQ; FALANO, OLUWASEUN CHUKWUMA}

\author{
Department of Physics, University of Port Harcourt, Port Harcourt, Nigeria \\ *rasaq.bello@uniport.edu.ng
}

\begin{abstract}
One of the geophysical techniques used in imaging the subsurface is the magnetic method via spectral analysis. To estimate the depth to basement and highlight spatial variations of various basement and sedimentary structures, an aeromagnetic data which lies within longitude $3^{0} 16^{\prime} \mathrm{E}$ to $3^{0} 25^{\prime} \mathrm{E}$ and latitude $7^{0} 06^{\prime} \mathrm{N}$ to $7^{0} 13^{\prime} \mathrm{N}$ was processed, analyzed and interpreted using spectral depth analytical technique with the aid of Arc GIS,Ms Excel and Origin Pro 8 Software's. In this study, Regional-residual separation was applied on the composite data and thereafter band pass filtering applied on the data using Ms excel software of the Orgin Pro 8. This filtering sectioned the residual into 9 spectral cells upon which Fast Fourier Transform (FFT) was performed. The FFT decomposed the residual into its frequency components and energy spectral segments. Log of the energy spectral was thus plotted against the radial frequency component. The plotted graphs revealed and identified two source depth models, $\mathrm{D}_{\mathrm{A}}$ and $\mathrm{D}_{\mathrm{B}}$. This estimated depths as evidenced with the depth contour map aided in delineating prospective areas. $\mathrm{D}_{\mathrm{A}}$ represents depth due to the long wavelength parts while $\mathrm{D}_{\mathrm{B}}$ is indicative of depth due to the short wavelength components. $\mathrm{D}_{\mathrm{A}}$ and $\mathrm{D}_{\mathrm{B}}$ vary from $1.9 \mathrm{~km}$ to 4.3 $\mathrm{km}$ but with an average depth of about $3.6 \mathrm{~km}$ and $0.09 \mathrm{~km}$ to $1.2 \mathrm{~km}$ but with an average of 0.9 $\mathrm{km}$ respectively. The average depth of $3.6 \mathrm{~km}$ suggests slight sedimentary thickness within the study. Hence, the possibility of the study area to slightly add to the economic reserve of the country cannot be ruled out when seismic sections are run over the area but where the data is a High resolution aeromagnetic data (HRAM), the result will probably be better. (C) JASEM https://dx.doi.org/10.4314/jasem.v21i2.1
\end{abstract}

Keywords: Aeromagnetic Data, Geochemistry, Abeokuta, spectral cells, intrusive, Basement.

The depth to basement has successfully been mapped and delineated using aeromagnetic data within sedimentary basins and volcanic areas. The study area found in Abeokuta has sparsely been studied by few researches whose aim vary from determination of hydrocarbon and mineral potential of the area, mapping of the geological and stratigraphic setting, to highlighting the tectonic framework of the area. As such many geological tools and geophysical methods including, Seismic, Landsat, gravity, aeromagnetic, geochemistry etc as well as geological mapping have been employed in their various studies. But according to Okonkwoet. al., (2012),hydrocarbon and mineral exploration of the subsurface involves some techniques and the magnetic method provides the most versatile of all the geophysical techniques to delineate the structure and lithology of the subsurface. Olowofelaet. al.,(2013) used aeromagnetic data via power spectrum in estimating the depth to basement. They obtained the mean shallow depth and deeper depths to be $0.467 \mathrm{~km}$ and $2.797 \mathrm{~km}$, respectively.Olurinet.al., (2015) used three (3) dimensional analysis in interpreting airborne magnetic data over Abeokuta and environs. In their analysis, depths to basement were examined with three approaches. According to their research, the Analystic signal approach revealed depths to vary from $0.554 \mathrm{~km}$ to $2.49 \mathrm{kmwhile}$ the horizontal gradient method (HGM) revealed the depth to range from $0.503 \mathrm{~km}$ to $2.34 \mathrm{kmand}$ the local wave number (LWN) gave the result to range from $0.931 \mathrm{~km}$ to $4.90 \mathrm{~km}$. This study therefore, estimated the depth to basement using spectral analytical technique using aeromagnetic data covering Abeokuta.

\section{MATERIALS AND METHODS}

The study was carried out in Abeokuta area of Ogun State, South western Nigeria. The area is located within longitude $3^{0} 16^{\prime} \mathrm{E}$ to $3^{0} 25^{\prime} \mathrm{E}$ and latitude $7^{0}$ $06^{\prime} \mathrm{N}$ to $7^{0} 13^{\prime} \mathrm{N}$. Ogun State is bounded in the west by Benin Republic, in the south by Lagos State, in the North by Oyo/Osun State and in the East by Ondo State Olowofelaet. al., (2013). Abeokuta is one of the most prominent urban settlements in the SouthWestern Nigeria. The gneiss-magnetite complex is the most widespread rock information within the study area. It comprises gneisses quartzite, calcsilicate, biotite-hornblende schist and 
amphibolites (Rahaman, 1976). The Older Granites around the Abeokuta area of late Precambrian age to early Palaeozoic in age are magmatic in the origin (Jones and Hockey, 1964). Abeokuta falls within the basement complex of the geological setting of SouthWestern Nigeria. The basement complex rocks of
Pre-Cambrian age are made up of older and younger granites, with younger and older sedimentary rocks of the tertiary and secondary ages. The area is underlain by basement rocks, which cover about $40 \%$ of landmass in Nigeria (Obaje, 2009). Figure 1 shows Abeokuta map.

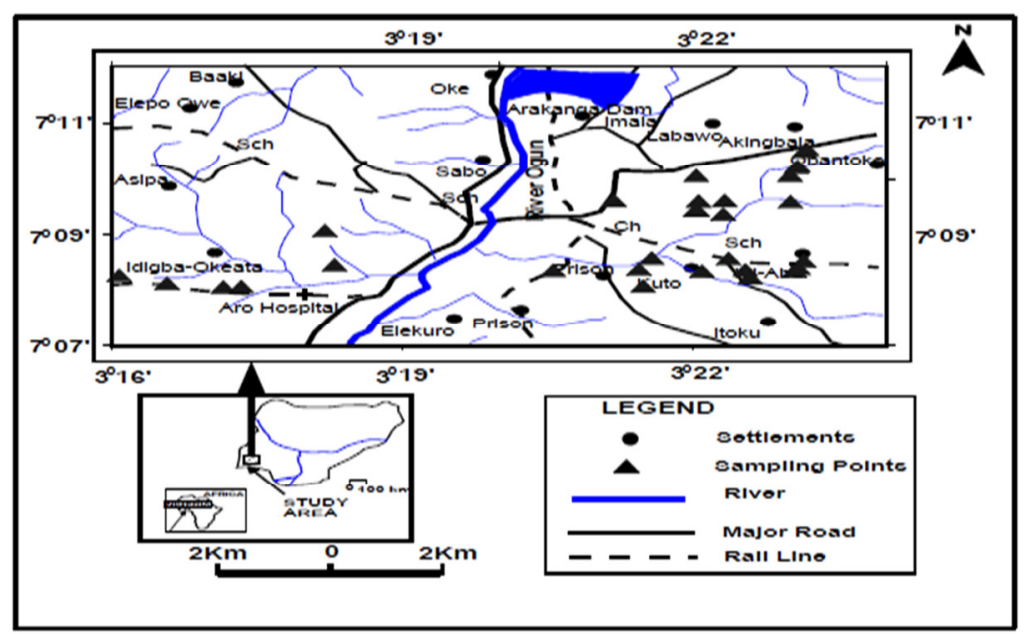

Fig 1: Abeokuta location map (Courtesy Aladejana and Talabi, 2013)

This work made use of aeromagnetic data of Abeokuta area of southwestern Nigeria. The data was obtained between 1979 and 1980 in a flight line direction of NW-SE. The fight ultitude occurred at about 260 meters while the tie line spacing occurs at $20 \mathrm{~km}$. For onward processing and interpretation, the data was opened and converted to a format usable by the sulfer 10 and Origin Pro 8 software's using the Arc GIS software. The Sulfer 10 was, thereafter used to generate the topographic map as $\mathrm{D}_{\mathrm{A}}$ was imported into Surfer 10 worksheet environment while the Origin Pro was used in determining the sedimentary thickness by partitioning or dividing the residual map into nine (9) spectral grids or cells using the filtering tool of the MS Excel sheet. This aided the depth parameter to be determined easily by means of Fast Fourier Transform (FFT) governed by equation one (1). The FFT was performed on each cell. The radial average energy (power) spectrum was therefore plotted in MS Excel using Excel chart wizard as Log of Energy (FFT magnitude) versus radial frequency in $\mathrm{Rad} / \mathrm{km}$. A straight line is then visually fit to the energy spectrum, both in the higher and lower frequency of the figure. The negative of slope of this line is equal to twice the depth to the center of mass of the bodies producing the magnetic anomaly.

$Y_{i}=f(x)=\sum_{n=1}^{N}\left[a_{n} \cos \left(\frac{2 n \pi x_{i}}{L}\right)+b_{n} \sin \left(\frac{2 n \pi x_{i}}{L}\right)\right]$

Where $Y_{i}=$ Reading at $x_{i}$

$\mathrm{L}=$ length of the cross - section of the anomaly

$\mathrm{n}=$ harmonic number of the partial wave

$\mathrm{N}=$ number of data point

$$
\begin{gathered}
a_{n}=\text { real path partial amplitude } \\
b_{n}=\text { imaginary path of FFT }
\end{gathered}
$$

\section{RESULTS AND DISCUSSION}

Table 1 summarizes depths values of various anomalous sources. The table shows two magnetic source models, $\mathrm{D}_{\mathrm{A}}$ and $\mathrm{D}_{\mathrm{B}}$ obtained from the slope, $M_{1}$ and $M_{2}$, of the graphs shown below. They graphs showthe various spectral energy curves. The depth to basement contour map (Fig 2) was generated using
$\mathrm{D}_{\mathrm{A}}$. Fig 2 shows contours that represents various locations of the anomalous sources. Most of contours are spaced and the rest closely parked. As validated by the legend beside the contour depth map, the spaced contours are indicative of the deeper seated bodies while the closely parked contours are good reflection of shallow anomalous sources. Visual inspection of the contour map also reveals thicker 
sediments occurring at the western and northern portion of the study area. Nevertheless, $D_{A}$ and $D_{B}$ indicate the deep and shallow seated magnetic (anomalous) sources respectively. The deeper sources regarded as the low frequency component is represented by the steep gradient of the spectral energy curve while the shallow magnetic bodies seen as the high frequency component is represented by the less steep gradient of the energy curve. The deeper magnetic sources are attributable to magnetic bodies on the basement surface and the shallow sources probably regarded as intrusives. The depths due to the deeper sources vary between $1.9 \mathrm{~km}$ and $4.3 \mathrm{~km}$ but with an average or true depth value of 3.6 $\mathrm{km}$. On the other hand, the shallower magnetic bodies lie between $0.09 \mathrm{~km}$ and $1.2 \mathrm{~km}$ but with an average depth of $1.047 \mathrm{~km}$. Maximum depth to basement of $4.33 \mathrm{~km}$ found in block 2 is located in the north western portion of the map whereas the minimum depth to basement of $1.9 \mathrm{~km}$ can be found in block 3 and is located in the north eastern portion of study area.

Table 1: Summary of depth to basement via spectral depth analysis

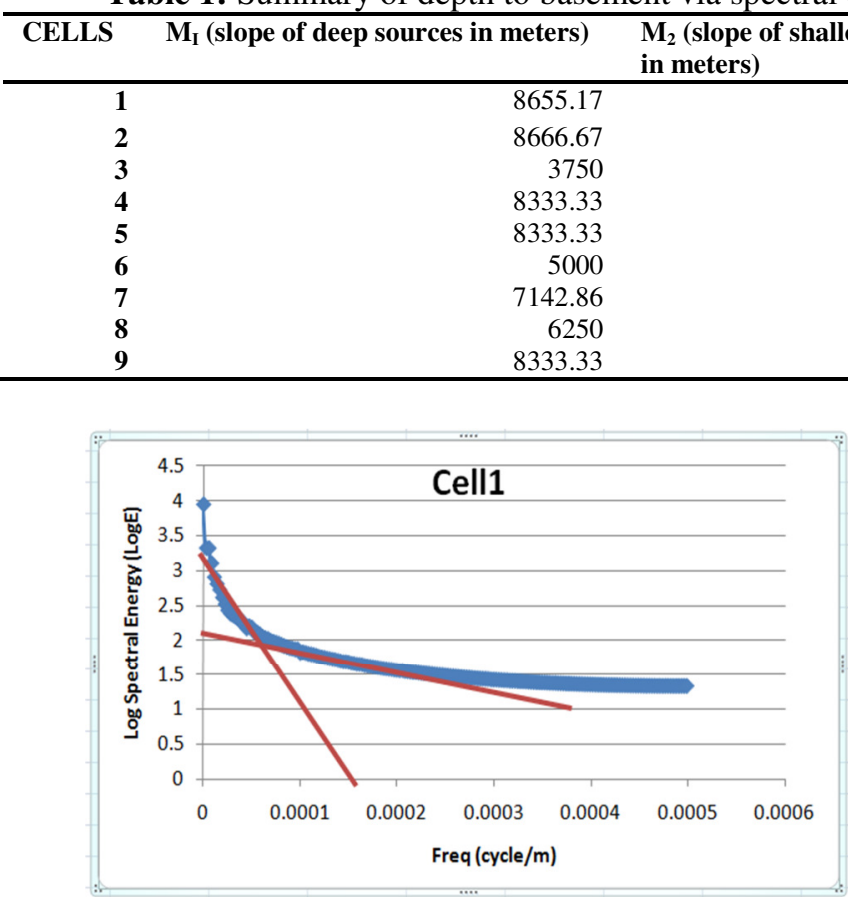

Log Power Spectrum for Cell 1

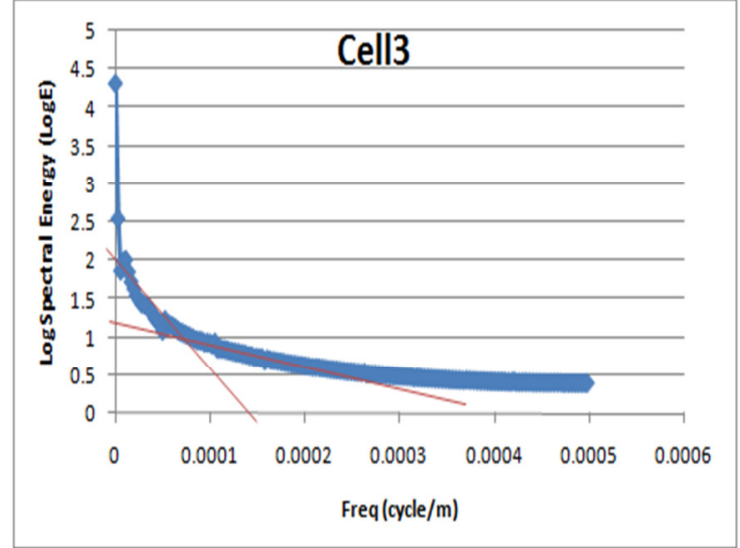

Log Power Spectrum for Cell 3

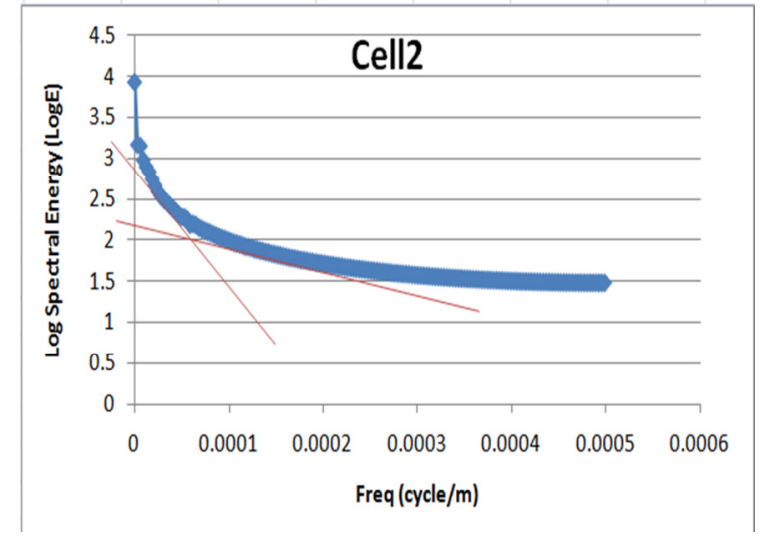

Log Power Spectrum for Cell 2

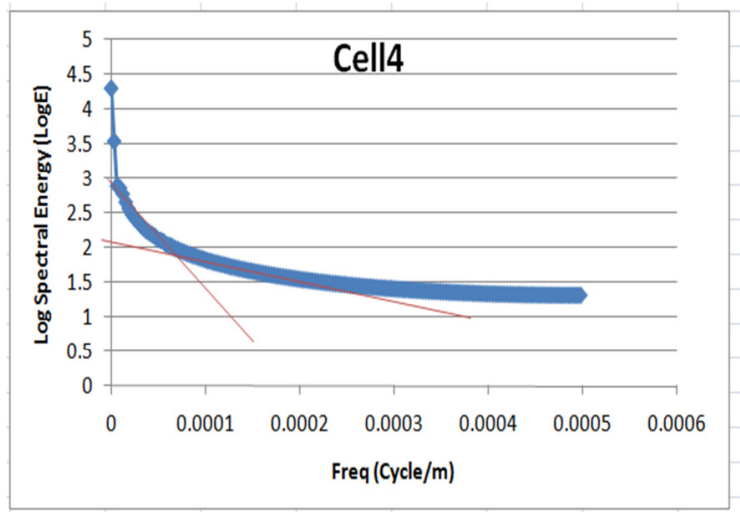

Log Power Spectrum for Cell 4 


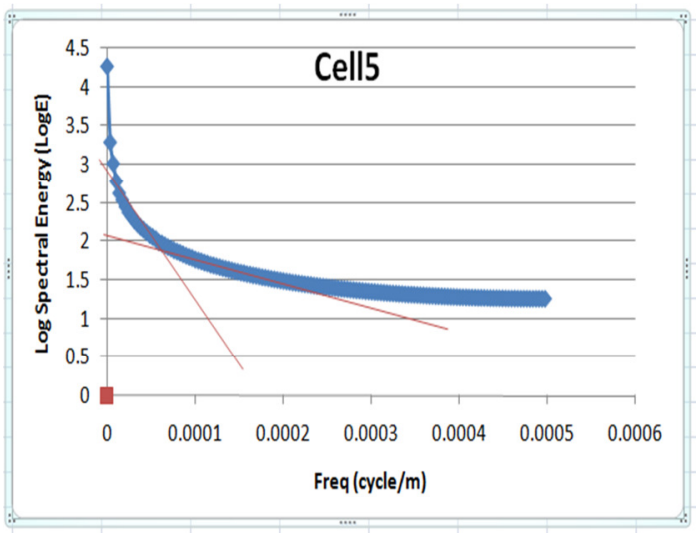

Log Power Spectrum for Cell 5

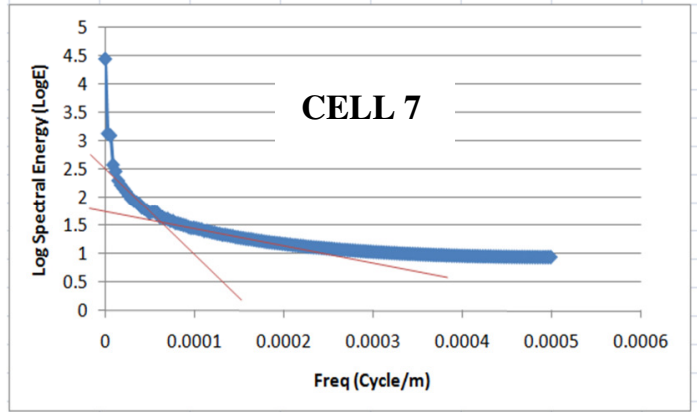

Log Power Spectrum for Cell 7

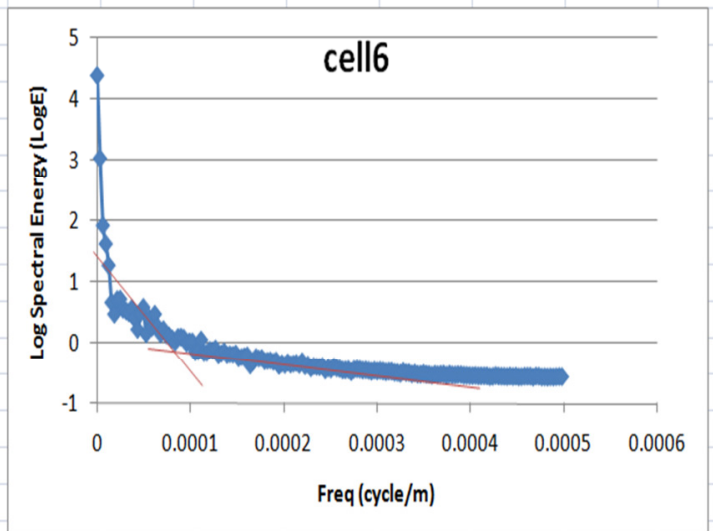

Log Power Spectrum for Cell 6

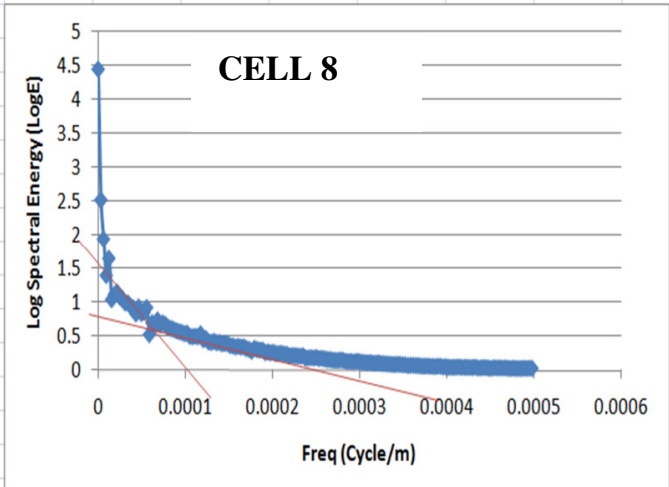

Log Power Spectrum for Cell 8

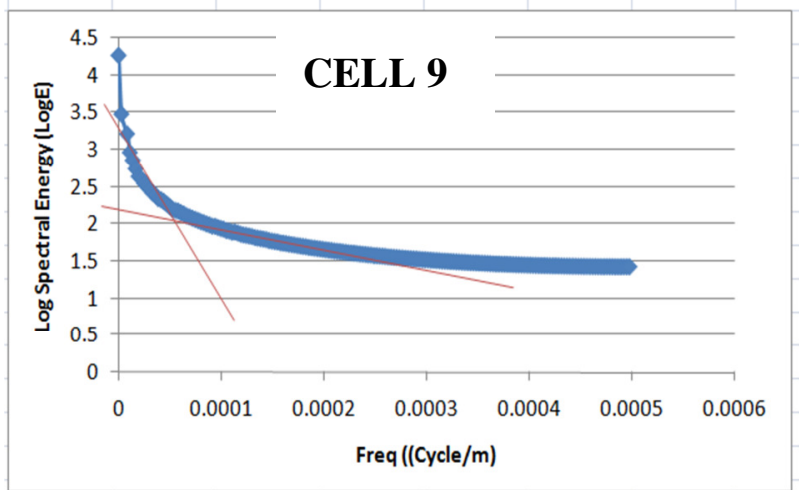

Log Power Spectrum for Cell 9

The significance of the result in terms of hydrocarbon and mineral exploration differs and also ties favourably with the results of some researches within and around the area.Olakunle and Abel (2013) mapped the basement topography aroundIjebu ode using aeromagnetic data. Using Euler Deconvolution method, they showed depth values ranging from 0.03 $\mathrm{km} 0.08 \mathrm{~km}$.Vitaliset. al., (2014) determined the thickness to sediments using the Peters half slope methodand depth of $2.40 \mathrm{~km}$ to $10.60 \mathrm{~km}$ for the very thin body, $1.8 \mathrm{~km}$ to $7.93 \mathrm{~km}$ for the intermediate body and $1.41 \mathrm{~km}$ to $6.35 \mathrm{~km}$ for the very thick body were revealed. Also, Olowofelaet. al., (2013) in a bid to determine the depth to basement obtained mean shallow depth and deeper depths to be $0.467 \mathrm{~km}$ and $2.797 \mathrm{~km}$ using aeromagnetic data via power spectrum. Olurinet.al., (2015) Used the analytic signal approach, Horizontal gradient method and the 
low wavenumber method in establishing the depth to basement within the study area. The Analystic signal approach revealed depths to vary from $0.554 \mathrm{~km}$ to $2.49 \mathrm{~km}$ while the horizontal gradient method (HGM) revealed the depth to range from $0.503 \mathrm{~km}$ to 2.34 $\mathrm{km}$ and the local wave number (LWN) gave the result to range from $0.931 \mathrm{~km}$ to $4.90 \mathrm{~km}$

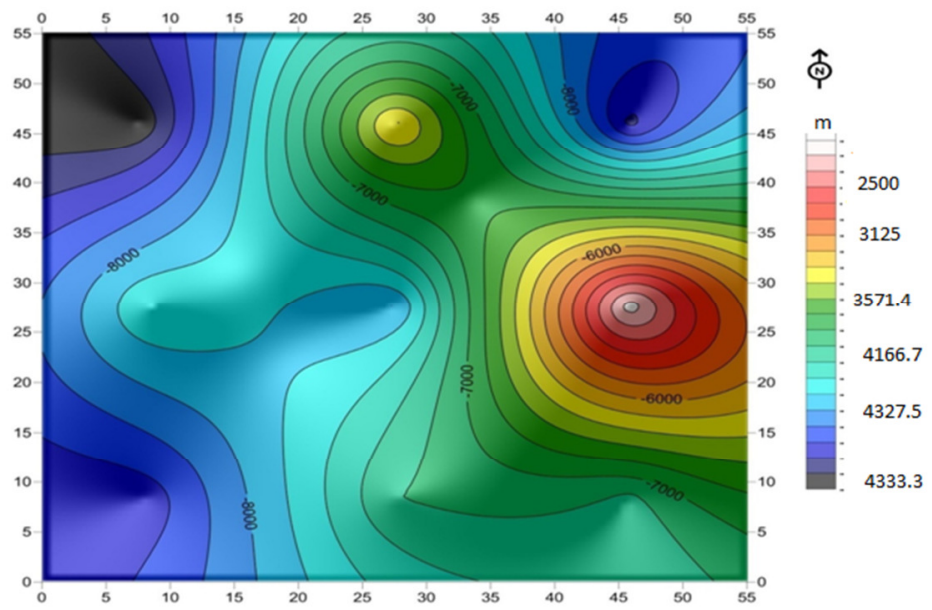

Fig 2: Depth to basement contour map

Conclusion: The result of the spectral analysis has established the fact that the study holds a slight promise for oil and gas as the maximum thickness obtained in this study falls within the average thickness value of 2.5 kmproposed by wright et. al., (1985).They proposed a sedimentary thickness of 2.5 $\mathrm{km}$ to be reached for such basin to be considered promising in terms of hydrocarbon exploration. Therefore, the need for the study area to be investigated in terms of its mineral potential.

\section{REFERENCES}

Aladejana, J.A. and Talabi AO (2013). Assessment of Groundwater Quality InAbeoukuta Southwestern, Nigeria, Research invent: International Journal of Engineering and Science $2,21-31$.

Jones, H.A. and Hockey, R.O. (1964): The Geology of Parts of Southwestern Nigeria. Bull. Geol. Surv. Nigeria 31: $101-102$.

Obaje, N.G. (2009): Geology and Mineral Resources of Nigeria. Springer, Berlin, Germany. 221.

Okonkwo, CC; Onwuemesi, AG; Anakwuba, EK; Chinwuko, AI; Ikumbur, EB; Usman, AO (2012). Aeromagnetic Interpretation over Maiduguri and Environs of Southern Chad Basin, Nigeria.Journal of Earth Sciences and Geotechnical Engineering, 2(2), 67-71.
Olakunle, O.O. and Abel, I.O. (2013): Aeromagnetic mapping of basement topography around the Ijebu-Ode geological transition zone, Southwestern, Nigeria. ActaGeodaetica et Geophysica, 48(4), 451-470.

Olowofela, J. A., Akinyemi, O.D., Idowu, O.A., Olurin, O.T. and Ganiyu, S.A. (2013): Estimation of magnetic basement depth Beneath the Abeokuta Area, South West Nigeria, Using Aeromagnetic Data. Asian Journal of Earth Sciences, 5(3), 70-78.

Olurin, O. T., Olowofela, J. A., Akinyemi, O. D., Badmus, B. S., Idowu, O. A. and Ganiyu, S. A. (2015): Enhancement and Basement Depth Estimation from Airborne Magnetic Data. The African Review of Physics, 10(38), 303-313.

Rahaman, M.A. (1976). A Review of the Basement Geology of South Western Nigeria. In: Geology of Nigeria. Geophysics 36(2), 112- 134.

Wright, J.B., Hastings, D.A., Jones, W.B. and Williams, H.R. (1985): Geology and Mineral Resources of West Africa, George Allen and Urwin, London, 90-120. 